\title{
ANALISIS ASPEK-ASPEK, IMPLIKASI DAN PENANGANAN MASALAH KEBIJAKAN PUBLIK PENERBITAN REKOMENDASI PERIJINAN REHABILITASI PASAR BANJARAN KABUPATEN BANDUNG PROVINSI JAWA BARAT
}

\author{
Asep Kusdiman Jauhari ${ }^{1 *}$, Afifah Latip Rasyid Jauhari ${ }^{2)}$ \\ ${ }^{1}$ Fakultas Ilmu Sosial dan Ilmu Politik, Universitas Pasundan \\ Bandung, Jawa Barat, Indonesia \\ hakjauhari@yahoo.co.id \\ ${ }^{2}$ Fakultas Ilmu Sosial dan Ilmu Politik, Universitas Pasundan \\ Bandung, Jawa Barat, Indonesia \\ afifahlatip@upi.edu
}

\begin{abstract}
ABSTRAK
Paradigma kepentingan ekonomi-kapitalistik untuk mendorong pertumbuhan ekonomi daerah melalui peningkatan Pendapatan Asli Daerah (PAD) menjadi paradigma yang dianut dalam Perda No.20/2009 Tentang Penataan, Pembangunan dan Pengendalian Pasar Kabupaten Bandung. Dalam pelaksanaannya, Pemerintah Kabupaten berada dalam posisi yang dilematis karena di satu sisi, Pemerintah Kabupaten ingin pembangunan pasar-pasar tradisional yang ada sebagai sumber PAD yang sangat potensial. Namun, di sisi lain, Pemerintah Kabupaten tidak mempunyai dana yang memadai dan konsep yang jelas untuk pembangunan pasar, sehingga cenderung bersikap kompromistis dengan pengembang sebagai pemilik modal.Modernisasi pasar untuk meningkatkan perekonomian pedagang kecil, dengan menerapkan manajemen pasar secara rasional, berorientasi pada standarisasi kualitas komoditas, standarisasi harga penjualan (fixed price), standarisasi fisik bangunan, dan lain-lain. mengembangkan kreativitas dalam pengelolaan pasar tradisional, misalnya dengan: membangun pasarpasar tematik bagi pengembangan pasar modern, seperti pasar yang khusus berjualan tekstil, elektronik, bahan bangunan, dan lainlain. melalui model ini diharapkan pasar modern tidak memonopoli seluruh komoditas yang menyebabkan daya saing pasar tradisional makin lemah. Pengembangan pasar secara tersebar, tidak bersifat linier mengikuti arus jalan, yang diharapkan dapat menciptakan pusat-pusat pertumbuhan baru di seluruh wilayah kota sekaligus meminimalkan penumpukan kegiatan ekonomi di satu wilayah yang dapat memicu terjadinya kesenjangan, kemacetan, dan melemahnya kapasitas lingkungan, bermuara pada pelayanan publik yang tidak prima.
\end{abstract}

Kata Kunci: Kebijakan Publik, Penerbitan Rekomendasi Perijinan dan Rehabilitasi Pasar.

\begin{abstract}
The paradigm of economic-capitalistic interests to encourage regional economic growth through increasing Regional Original Income (PAD) is the paradigm adopted in Perda No.20 / 2009 concerning Structuring, Development and Control of the Bandung Regency Market. In its implementation, the district government is in a dilemma because on the one hand, the district government wants the development of existing traditional markets as a potential source of PAD. However, on the other hand, the district government does not have adequate funds and a clear concept for market development, so it tends to compromise with developers as owners of capital. Market modernization is to improve the economy of small traders, by implementing rational market management, oriented towards standardizing quality commodities, standardized selling prices (fixed prices), standardized physical buildings, and others. developing creativity in traditional market management, for example by: building thematic markets for the development of modern markets, such as a market that specializes in selling textiles, electronics, building materials, and others. Through this model it is hoped that the modern market will not monopolize all commodities which causes the competitiveness of traditional markets to become weaker. Market development is spread, not linear with the flow of the road, which is expected to be able to create new growth centers throughout the city while minimizing the accumulation of economic activity in one area that can trigger gaps, congestion, and weakening environmental capacity, leading to public services which is not prime.
\end{abstract}

Keywords: Public Policy, Issuance of Licensing Recommendations and Market Rehabilitation. 


\section{Kebijakan: Jurnal Ilmu Administrasi \\ Volume 12, Nomor 1, Januari 2021 \\ E-ISSN: 2656-2820 \\ P-ISSN 1829-5762}

\section{PENDAHULUAN}

Secara umum tujuan pembangunan pasar adalah untuk membangkitkan daya saing pasar, membangkitkan pergerakan ekonomi pasar dan kesejahteraan masyarakat. Melalui peningkatan kesejahteraan ini diharapkan menjadi feedback kesejahteraan menjadi meningkat pula.Lebih dari itu peningkatan daya saing diharapkan dapat membangkitkan minat investasi. Peningkatan investasi ini akan mempercepat pertumbuhan ekonomi di sekitar pasar. Era perdagangan bebas menuntut kesigapan kita, alih-alih mengimbangi persaingan dengan masyarakat internasional, Indonesia harus melakukan konsolidasi dalam berbagai bidang termasuk bidang ekonomi di dalamnya.Pasar tradisional merupakan denyut nadi ekonomi masyarakat Indonesia sesungguhnya dan vital.Namun demikian kondisi umum pasar tradisional saat ini sangat memprihatinkan karena stagnan dan cenderung menurun produktifitasnya.

Mempertahankan keberadaan pasar tradisional ini diperlukan kesungguhan dan komitmen dari berbagai pihak terkait.Pasar tradisional yang baik harus dapat menjadi tempat yang menarik untuk melakukan tawar menawar, transaksi, interaksi sosial, bernilai ekonomis, dapat mendorong termanfaatkanya potensi daerah, menjadi lokomotif pertumbuhan ekonomi daerah dengan penglolaan yang profesional. Kemudian permasalahan mendasar pasar tradisional sebenarnya dapat ditinjau dari beberapa aspek. Keterpurukan pasar tradisional secara makro disebabkan oleh:

(a). Persaingan tidak seimbang dengan pasar modern (ditinjau dari aspek akses informasi, modal, lahan/bangunan dan SDM);

(b). Perubahan gaya hidup \& pola konsumsi terkait pendapatan dan budaya masyarakat;

(c). Pemahaman dan keberpihakan pemerintah yang rendah terhadap pasar tradisional;

(d). Ketidaksinambungan implementasi kebijakan vertikal dan horizontal yang ada.

Beberapa praktek pengelolaan dan operasionalisasi pasar yang dinilai tidak efektif ini disebabkan oleh beberapa hal sebagai berikut:

a) Dualisme pengelolaan;

b) Arah pengembangan pasar yang tidak jelas, baik secara fisik, transaksi dan kekeluargaan;

c) Ketiadaan standar O \& M pasar;

d) Minimnya akuntabilitas dan transparansi retribusi serta kaitannya dengan pemeliharaan fasilitas dan kualitas layanan;

e) Ketiadaan upaya akomodasi karakteristik dan peningkatan kapasitas pedagang, unit penjualan dan komoditas pada pengelolaan. Sejumlah upaya penanganan keterpurukan pasar tradisional sudah dilaksanakan di beberapa daerah. Sayangnya, upaya ini seringkali mengalami kegagalan yang menyebabkan kondisi pasar tradisional ini semakin terancam keberadaannya.

Pasar Banjaran mempunyai potensi kios sebanyak 549 unit dan lapangan 553 unit dengan cakupan layanan sekitar 322.593 orang, meliputi wilayah pelayanan Kecamatan Pameungpeuk, Banjaran, Cimaung dan Cangkuang. Pasar Banjaran mengemban tugas yang berat dalam mengembangkan ekonomi rakyat di wilayah Tengah Kabupaten Bandung. Keberadaannya diharapkan dapat membangkitkan perekonomian melalui perluasan lapangan kerja dan usaha. Pembangunan kembali (revitalisasi) Pasar Banjaran dimaksudkan agar pelayanan kepada masyarakat menjadi lebih baik.Pelayanan ini tentu harus memenuhi unsur kemudahan, kenyamanan, kebersihan, kesehatan, murah dan bernilai ekonomis.Kemudian pembangunannya tidak terlepas dari maksud pemerintah daerah dalam peningkatan sarana dan prasarana ekonomi masyarakat. Keberadaan pasar yang berkembang tentu pada gilirannya akan meningkatkan Pendapatan Asli Daerah (PAD). Secara khusus pemenuhan kebutuhan, higienitas, dan kemudahan memperoleh barang dan barang-barang lainnya dengan tingkat harga yang wajar bagi konsumen terus meningkat seiring dengan pertumbuhan penduduk dan perekonomian. Kondisi tersebut ternyata belum sepenuhnya diimbangi oleh tingkat sarana prasarana perekonomian yang memadai, khususnya fisik pasar tradisional. Untuk itu 
dibutuhkan pasar yang representatif dalam melayani dan memenuhi supply dan demand. Terdapat beberapa kendala internal cukup serius yang dihadapi Pasar Banjaran, diantaranya, adalah:
(a). Pelayanan pasar terhadap pedagang yang kurang nyamanan.
(b). Penataan tata ruang belum optimal.
(c). Komoditas unggulan belum menjadi ikon pasar.
(d). Kemacetan dan lingkungan kotor dan kumuh.
(e). Persepsi antara pedagang dalam memperjuangkan kepentingan belum optimal.
(f). Permasalahan terkait pembayaran retribusi.
(g). Lemahnya bargaining position ketika berhadapan dengan usaha skala besar.

Kendala eksternal, diantaranya, adalah:

a) Rendahnya penegakan hukum, misalnya keberadaan PKL di sekitar pasar.

b) Penataan lingkungan pasar belum maksimal, sehingga menimbulkan kemacetan.

c) Timbulnya kompetisi perdagangan dengan pihak luar, khususnya dengan PKL, pertokoan dan Pasar Modern.

Pasar Banjaran sebagai pusat kegiatan ekonomi rakyat perlu didorong dan dikembangkan secara optimal, mengingat pengaruhnya terhadap kehidupan masyarakat.Oleh karena itu, untuk peningkatan daya saing dalam peningkatan eksisitensinya maka sudah selayaknya Pasar Banjaran dibangun sesuai dengan tujuan keberadaannya. Namun demikian pembangunan tersebutharus dilakukan dengan seksama. Hal ini ditujukan agar pembangunan pasar dapat mengakomodir seluruh kepentingan stakeholders dan agar pasar dapat bertahan terhadap perubahan di masa datang. Lebih dari itu pasar harus dapat mengakomodir potensi yang ada di wilayah Kecamatan Banjaran, baik potensi Sumberdaya Alam maupun Sumberdaya Manusia.

Beberapa hal yang perlu diperhatikan dalam pengembangan tersebut, seperti aspek sosial dan ekonomi pasar. Aspek sosial ekonomi sangat berpengaruh terhadap keberadaan pasar, seperti: kondisi demografi, ketersediaan sarana prasarana, budaya, daya beli, dll. Harapan terhadap keberadaan pasar dengan pelayanan prima, ketersediaan beragai ragam kuantitas/kualitas barang, harga yang kompetitif, tempat yang nyaman, bersahabat dan sebagai pusat pengembangan budaya local adalah tujuan pembangunan pasar.Terkait dengan tujuan pembangunan pasar tersebut maka dilakukan kegiatan analisis sosial ekonomi Pasar Banjaran. Kegiatan ini bertujuan untuk memberikan saran terhadap pembangunan pasar yang sesuai kebutuhan masa kini dan masa yang akan datang untuk memberikan pelayanan public yang prima. Berkaitan dengan hal tersebut, maka tujuan kajian ini adalah:

(a). Melakukan identifikasi permasalahan sosial, ekonomi, arsitektural dan pembiayaan/investasti dalam terkait pembangunan Pasar.

(b). Menyusun analisis dan rumusan permasalahan sosial, ekonomi, arsitektural dan pembiayaan/investasti dalam terkait pembangunan Pasar.

(c). Menyusun way out (jalan keluar) dalam penanggulangan permasalahan yang terjadi akibat pembangunan Pasar Banjaran.

(d). Menyusun panduan terhadap aspek sosial dan ekonomi dalam pembangunan Pasar.

\section{METODE}

Kajian teoretik memberikan rumusan hipotesis, selanjutnya rumusan tersebut dicek dengan kondisi lapangan melalui studi ke lapangan yang dikaji dalam kajian empirik. Kajian empirik memberikan fakta-fakta kondisi eksisting lokasi renovasi pasar dan faktor-faktor yang akan terpengaruh dalam pembangunannya tersebut. Sintesis yang telah terumuskan akan menjadi sebuah gagasan umum tentang konsep renovasi pasar yang diharapkan dapat meningkatkan produktifitas 
Kebijakan: Jurnal Ilmu Administrasi

Volume 12, Nomor 1, Januari 2021

E-ISSN: 2656-2820

P-ISSN 1829-5762

masyarakat sekaligus mengurangi dampak sosial ekonomi yang tidak diharapkan. Indikasi-indikasi yang diperoleh dari sintesis yang dilakukan selanjutnya diperjelas dengan membuat rumusanrumusan. Rumusan ini juga dijabarkan berdasarkan jenis-jenis data yang ada, yang terdiri atas: datadata berkaitan kondisi eksisting keberadaan lokasi keberadaan pasar, dengan kerangka analisis yang dipergunakan dapat dilihat pada bagan 1 .

Bagan 1. Kerangka Analisis

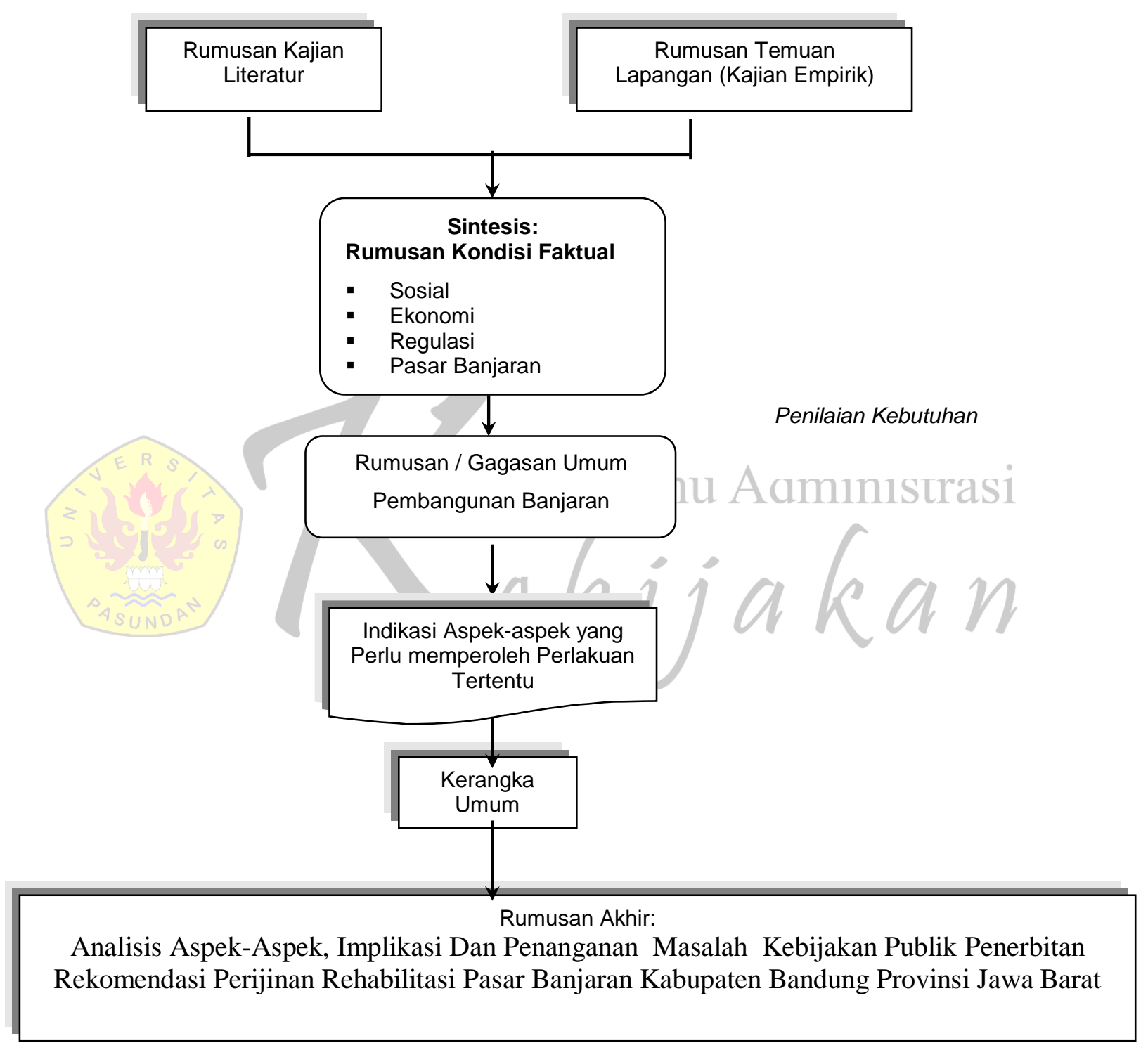

Sumber: Hasil Analisi Tahun 2013.

\section{PEMBAHASAN}

\section{Kondisi Sosial Ekonomi Daerah Sekitar Pasar}

\section{Kondisi Sosial Daerah Sekitar Pasar}

Keberadaan pasar dan kawasan niaga sekitarnya berpengaruh secara segnifikan terhadap kehidupan masyarakat sekitar pasar. Hal ini karena pasar dan daerah sekitarnya merupakan simpul 
berkumpul dan mobilitas Manusia dan barang. Berikut ini kondisi sosial ekonomi masyarakat dan lingkungan sekitar pasar sebelum dan sesudah pembangunan dilakukan.

Tabel 1. Kondisi Sosial Daerah Sekitar Pasar

\begin{tabular}{|c|c|}
\hline Aspek Sosial & Kondisi Daerah Sekitar Pasar \\
\hline $\begin{array}{l}\text { Perebutan/Penggunaan } \\
\text { Ruang Publik Untuk } \\
\text { Kegiatan Pribadi }\end{array}$ & $\begin{array}{l}\text { Perebutan ruang publik terjadi tidak terlepas dari faktor ekonomis. } \\
\text { Keberadaan pasar berdampak terhadap peningkatan nilai ekonomis daerah } \\
\text { sekitar pasar. Sehingga terjadi perebutan ruang publik dengan motif } \\
\text { ekonomis. Ruang publik tersebut diantaranya: trotoar, bahu jalan, halte,dll }\end{array}$ \\
\hline $\begin{array}{l}\text { Wajah pasar } \text { kotor, } \\
\text { kumuh, tidak indah } \\
\text { dan tidak sehat }\end{array}$ & $\begin{array}{l}\text { Karena mobilitas manusia dan barang tinggi maka limbah dari pergerakan } \\
\text { tersebut dapat berakibat wajah pasar dan daerah sekitarnya menjadi } \\
\text { kurang menarik dan tidak sehat. Limbah dimaksud diantaranya: asap } \\
\text { knalpot, sampah, poster, papan iklan, dll }\end{array}$ \\
\hline $\begin{array}{lr}\text { Timbulnya } & \text { Gangguan } \\
\text { Keamanan } & \text { dan } \\
\text { Ketertiban } & \end{array}$ & $\begin{array}{l}\text { Pasar sebagai simpul pergerakan dan pengumpulan manusia dan barang } \\
\text { mempunyai mobilitas yang tinggi dengan intensitas yang tinggi. Hal } \\
\text { berakibat terhadap gangguan lalu lintas. Gangguan tersebut, diantaranya } \\
\text { timbulnya kemacetan, kenyamanan berkendaraan menjadi berkurang, } \\
\text { gangguan keamanan, polusi, dll }\end{array}$ \\
\hline $\begin{array}{l}\text { Timbulnya } \quad \text { Penyakit } \\
\text { Masyarakat }\end{array}$ & $\begin{array}{l}\text { Pertumbuhan ekonomi area pasar dan lingkungan sekitarnya yang tinggi } \\
\text { mendorong masyarakat untuk memanfaatkan kondisi tersebut. Karenanya } \\
\text { akan tumbuh berbagai kegiatan ekonomis, salah satunya kegiatan } \\
\text { ekonomis yang melanggar norma/etika/kepatutan masyarakat. Kegiatan } \\
\text { tersebut diantaranya: gelandangan pengemis, WTS, pengamen, dll }\end{array}$ \\
\hline $\begin{array}{l}\text { Meningkatnya } \\
\text { Permasalahan Lalu } \\
\text { Lintas }\end{array}$ & $\begin{array}{l}\text { Mobilitas manusia dan barang yang tinggi berakibat terjadinya gangguan } \\
\text { terhadap kondisi lalu lintas daerah sekitar pasar. Gangguan tersebut, } \\
\text { diantaranya, adalah; terjadinya kemacetan yang berkepanjangan, } \\
\text { kecelakaan, kenyamanan, dll }\end{array}$ \\
\hline $\begin{array}{l}\text { Tumbuhnya PKL dan } \\
\text { Sektor/Kegiatan } \\
\text { Informal Lain }\end{array}$ & $\begin{array}{l}\text { Keberadaan pasar berdampak terhadap peningkatan nilai ekonomis daerah } \\
\text { sekitar pasar. Keadaan ini menimbulkan tumbuhnya usaha/kegiatan } \\
\text { informal, diantatanya, adalah: tumbuhnya PKL dan parkir liar, dan } \\
\text { usaha/kegiatan informal lainnya. }\end{array}$ \\
\hline $\begin{array}{l}\text { Terjadinya } \\
\text { Pencemaran, Sampah, } \\
\text { Banjir dan Penebangan } \\
\text { Pohon }\end{array}$ & $\begin{array}{l}\text { Pencemaran terjadi karena ambang batas limbah melebihi ketentuan. } \\
\text { Pencemaran tersebut, diantaranya: pencemaran udara, sampah, limbah } \\
\text { pasar, dll. Sampah sebagai limbah pasar merupakan permasalahan } \\
\text { tersendiri. Hal ini karena pasar menghasilkan sampah dalam jumlah besar } \\
\text { dengan jenis yang beragam. Sampah berakibat terhadap aroma, kotor, } \\
\text { kesehatan, dll. Kondisi lain yang tidak diharapkan, adalah terjadinya } \\
\text { banjir di area pasar. Banjir ini diakibatkan karena tidak berfungsinya } \\
\text { saluran air dan kuantitas sampah yang tidak tertampung. Lebih dari itu, } \\
\text { motif ekonomi mendorong pengorbanan pepohonan sebaga buffer } \\
\text { lingkungan. }\end{array}$ \\
\hline $\begin{array}{l}\text { Tingginya penggunaan } \\
\text { sarana prasarana. }\end{array}$ & $\begin{array}{l}\text { Berkumpulnya manusia dan barang berakibat terhadap tingginya intensitas } \\
\text { penggunaan sarana prasarana. Kondisi ini berakibat usia efektif sarana } \\
\text { prasarana berkurang. Sehingga frekuensi perbaikan/pembuatan sarana } \\
\text { prasarana menjadi tinggi. }\end{array}$ \\
\hline Pertumbuhan & Secara ekonomis daerah sekitar pasar cukup menarik. Keadaan ini \\
\hline
\end{tabular}


Sumber: Analisis Sosial Ekonomi Pembangunan Pasar Banjaran 2013.

\section{Kondisi Ekonomi Daerah Sekitar Pasar}

Keberadaan pasar sebagai entitas ekonomi berpengaruh besar terhadap perekonomian daerah sekitar pasar.Secara umum keberadaan pasar berpengaruh positif terhadap perekonomian daerah sekitar pasar.Untuk lebih jelasnya mengenai hal tersebut dapat dilihat pada table di bawah ini.

Tabel 2. Kondisi Ekonomi Daerah Sekitar Pasar

\begin{tabular}{|l|l|}
\hline Aspek Ekonomi & \multicolumn{1}{|c|}{ Kondisi Daerah Sekitar } \\
\hline $\begin{array}{l}\text { Pertumbuhan } \\
\text { Kegiataan }\end{array}$ & $\begin{array}{l}\text { Permintaan (demand) pasar mendorong kreatifitas penduduk untuk } \\
\text { memenuhinya. Kreatifitas ini berakibat tumbuhnya usaha-usaha penduduk. } \\
\text { Pertumbuhan usaha penduduk membuka lapangan kerja dan peningkatan } \\
\text { kesejahteraan penduduk. }\end{array}$ \\
\hline $\begin{array}{l}\text { Bangkitan } \\
\text { Ekonomi }\end{array}$ & $\begin{array}{l}\text { Kapitalisasi besar, kegiatan ekonomis dan mobilitas tinggi, dan banyaknya } \\
\text { komponen yang terlibat menjadikan pasar sebagai bangkitan ekonomi. } \\
\text { Bangkitan ekonomi ini mendorong kegiatan ekonomi di wilayah lain. }\end{array}$ \\
\hline $\begin{array}{l}\text { Peningkatan } \\
\text { Nilai Ekonomis }\end{array}$ & $\begin{array}{l}\text { Peningkatan nilai ekonomis, seperti meningkatnya harga tanah, tingginya biaya } \\
\text { hidup, dll merupakan konsekuensi dari kegiatan ekonomi yang memusat (pasar). } \\
\text { Peningkatan ekonomis ini merupakan nilai tambah bagi penduduk sekitar pasar. }\end{array}$ \\
\hline
\end{tabular}

Sumber: Analisis Sosial Ekonomi Pembangunan Pasar Banjaran 2013.

3. Interaksi Pasar Banjaran Dengan Wilayah Sekitar

Secara luas keberadaan Pasar Banjaran berpengaruh pula terhadap wilayah sekitarnya.Bukan saja karena pasokan barang dari produsen, namun juga terkait dengan skala layanan yang luas, meliputi wilayah Kecamatan Banjaran dan sekitarnya.Untuk lebih jelasnya mengenai interaksi Pasar Banjaran terhadap wilayah layanannya dapat dilihat pada tabel di bawah ini.

Tabel 3. Interaksi Pasar Banjaran Dengan Wilayah

\begin{tabular}{|l|l|}
\hline $\begin{array}{c}\text { Aspek Interaksi } \\
\text { Wilayah }\end{array}$ & \multicolumn{1}{c|}{ Keterkaitan Pasar Banjaran-Wilayah Sekitar } \\
\hline Sumber Barang & $\begin{array}{l}\text { Wilayah sekitar pasar merupakan produsen berbagai produk, diantaranya: } \\
\text { pertanian, perikanan, peternakan, kerajinan, kain/pakaian, sepatu/sandal, dll. } \\
\text { Keterkaitan pasar dengan produsen cukup erat karena ke dua komponen ini } \\
\text { saling membutuhkan. Wilayah tersebut, terdiri dari: Kecamatan Pameungpeuk, } \\
\text { Arjasari, Majalaya, Ciparay, Cimaung, Pangalengan, Cangkuang, Soreang, } \\
\text { Ciwidey. Sementara wilayah Kota Bandung, diantaranya: Cigondewah, Pasar } \\
\text { Baru, Pasar Andir/Ciroyom, Cibaduyut, dan Pasar Lainnya. }\end{array}$ \\
\hline Pembeli Potensial & $\begin{array}{l}\text { Pembeli potensial pasar berasal dari wilayah sekitar Kecamatan Banjaran. } \\
\text { Secara spesifik, pembeli potensial dari Kecamatan Pameungpeuk, terbanyak, } \\
\text { adalah karyawan/buruh pabrik dan warung makan/kantin. Pembeli potensial } \\
\text { wilayah lainnya, adalah ibu rumah tangga dam masyakarat umum. Keterkaitan } \\
\text { pasar dengan pembeli potensial tersebut sangat erat, ke dua komponen ini } \\
\text { saling bergantung satu sama lainnya. }\end{array}$ \\
\hline
\end{tabular}




\begin{tabular}{|l|l|}
\hline Kegiatan Pasar & $\begin{array}{l}\text { Sebagai pasar tradisional Pasar Banjaran mempunyai fungsi sosial, selain } \\
\text { fungsi ekonomis. Bahkan sebagian penduduk memanfaatkan pasar sebagai } \\
\text { tempat rekreasi dan wisata. Kegiatan-kegiatan pasar tersebut mempererat } \\
\text { ikatan antara pasar dengan penduduk. }\end{array}$ \\
\hline Sistem Distribusi & $\begin{array}{l}\text { Sistem distribusi pasar berjalan secara bertingkat dan berjenjang. Pasar } \\
\text { mendapatkan pasokan barang dari produsen. Sementara pasar melakukan } \\
\text { distribusi secara langsung kepada masyarakat atau melalui warung, toko, kios, } \\
\text { dan jenis ritel lainnya. Sistem distribusi pasar menyebabkan } \\
\text { keterkaitan/interaksi antar wilayah menjadi intensif dan frekuensi yang tingi. }\end{array}$ \\
\hline
\end{tabular}

Sumber: Analisis Sosial EkonomiPembangunan Pasar Banjaran 2013.

\section{Pembangunan(Revitalisasi) Pasar Banjaran}

1. Persepsi Terhadap Pembangunan Pasar

Persepsi Pedagang Terhadap Pembangunan Pasar tentu sangat beragam. Kepemilikan Hak Guna Pakai kios/los merupakan asset bagi pedagang.Kios dan los bernilai ekonomis, baik sebagai matapencaharian maupun untuk diperjualbelikan.Pemindahan hak kepemilikan kios dan los memiliki nilai yang tinggi yang dapat melebihi harga dari kios dan los yang dibangun.Sehingga kios dan los tersebut menjadi asset yang negatif.Kemudian untuk biaya pembangunan acuan melihat biaya pembangunan swadaya oleh pedagang.Hal lainnya, yaitu pembangunan pasar yang mahal tersebut belum tentu dapat meningkatkan keramaian dan pendapatan pedagang. Sementara persepsi negatif terhadap developer masih tinggi.Karena developer dipandang mempunyai misi mencari keuntungan belaka dan mengabaikan misi lainnya, seperti pemberdayaan ekonomi rakyat dan lainnya. Kinerja kurang baik pembangunan pasar tradisional yang telah dilakukan merupakan pertimbangan lain terhadap antusiasme pedagang dalam pembangunan Pasar Banjaran.

Tabel 4. Persepsi Pedagang Terhadap Pembangunan Pasar

\begin{tabular}{|l|c|}
\hline \multicolumn{1}{|c|}{ Persepsi Pedagang Terhadap Pembangunan Pasar } & $\begin{array}{l}\text { Pendapat } \\
\text { Pedagang }\end{array}$ \\
\hline $\begin{array}{l}\text { Pasar harus dapat melakukan peningkatan pelayanan, keragaman komoditi, } \\
\text { kenyamanan dan keamanan kepada konsumen }\end{array}$ & $\sqrt{ }$ \\
\hline Pembangunan pasar dapat meningkatkan minat berkunjung ke pasar & $\sqrt{ }$ \\
\hline Harga komoditas menjadi lebih mahal & $\sqrt{ }$ \\
\hline $\begin{array}{l}\text { Pembangunan pasar belum tentu dapat mengatasi kemacetan, PKL dan } \\
\text { permasalahan kebersihan, keamanan dan ketertiban, dan kenyamanan } \\
\text { wilayah sekitar pasar }\end{array}$ & $\sqrt{ }$ \\
\hline $\begin{array}{l}\text { Pembungan pasar harus meliputi pula penataan terminal dan penertiban } \\
\text { area sekitar pasar sesuai peruntukannya }\end{array}$ & \multicolumn{2}{|}{} \\
\hline
\end{tabular}

Sumber: Analisis Sosial Ekonomi Pembangunan Pasar Banjaran 2013.

\section{Keberatan Terhadap Pembangunan Banjaran}

Keberatan Terhadap Keberadaan Pasar Banjaran saat ini diantaranya Kkeberatan konsumen dan pedagang terhadap Pasar Banjaran secara umum (saat ini), terdiri keberadaan terhadap: ukuran toko/kios/ls kurang memadai, retribusi mahal, kemacetan lalu lintas, keberadaan PKL/Pasar Tumpah,kenyaman berdagang kurang, faktor keselamatan kurang, area parkir memadai, fasos dan fasum kurang memadi, penerangan kurang, penataan komoditas kurang bagus, drainase dan ketersediaan air kurang, keragaman produk kurang, lorong/gang kurang lebar dan fasilitas bongkar 
muat kurang memadai. Keberatan Terhadap Pembangunan Pasar Banjaran. Keberatan terhadap pembangunan Pasar Banjaran, diantaranya, adalah: karena harga toko/kios/los menjadi mahal, terjadi pengurangan/perubahan lokasi dan ukuran kios, kemungkinanan tidak mendapat toko/kios/los, pasar akan menjadi kurang laku, pembangunan dilakukan melalui relokasi dan karena alasan lainnya.

3. Harapan dan Saran Masyarakat Terhadap Pembangunan Pasar Banjaran

Hasil kuisiner menunjukan pembangunan Pasar Banjaran harus dapat meningkatkan kelancaran lalu lintas, pasar teratur dan tidak semrawut, tidak ada PKL/pasar tandingan, PKL diakomodir dalam pembangunan, pembanguna pasar modern dibatasi, pasar semakin nyaman dan bersih, pasar tidak perlu dipembangunan, harus dilakukan sosialisasi, pintu keluar/masuk harus diperhatikan, faktor keselamatan diperhatikan, renovasi dapat dijadikan 2 lantai, parkir harus dapat menampung kendaraan, harga toko/kios/los murah, letak dan ukuran kios jangan dirubah, pembangunan harus menghasilkan pendapatan lebih tinggi (laku), pembangunan tidak merugikan padagang, pembeli/konsumen harus diarahkan secara merata, fasos/fasum-khususunya tempat ibadah harus nyaman dan memadai, dan pasar dibagian belakang harus menjadi lebih ramai.

4. Pengaruh PembangunanPasar Banjaran Terhadap Usaha Pedagang

Menurut sebagian pedagang pembangunan berpengaruh terhadap peningkatan usaha, sementara sebagian pedagang menyatakan pembangunan tidak berpengaruh terhadap peningkatan usaha, sementara sebagian pedagang menyatakan ketidaktahuannya terhadap pengaruh pembangunan terhadap usaha mereka. Apabila pasar seperti pasar modern maka pasar bisa bersaing untuk memperebutkan pelanggan. Sementara bagi pedagang yang menyatakan bahwa pembangunan tidak berpegaruh terhadap usaha mereka didasari oleh alasan bahwa pembangunan pasar tradisional tidak pernah ada yang berhasil.

5. Pembangunan Pasar Banjaran Ideal

Pembangunan ideal yang diharapkan oleh pedagang, diantaranya, adalah: harga jual/sewa toko/kios/los murah (terjangkau), ukuran toko/kis/ls tetap memadai sesuai usaha, pembangunan harus dapat meningkatkan pendapatan, pasar menjadi bersih dan teratur, pasar harus lebih nyaman, area parkir harus dapat menampung kendaraan, peningkatan keamanan dan ketertiban, tidak ada lagi PKL/Pasar Tumpah, bangunan harus menarik, pembangunan dapat memperlancar lalu lintas, menyediakan fasos dan fasum yang memadai, tersedia sarana prasarana bongkar muat, dan meningkatkan penerangan, drainase, dan pasokan air.

6. Komitmen Terhadap PembangunanPasar Banjaran.

Antusias dukungan pedagang tampak masih kurang. Kurang antusiasnya dukungan ini diakibatkan oleh beberapa hal, diantaranya, adalah: daya beli kios/los dianggap belum bisa mencukupi, harga kios/los yang terlalu tinggi, pembangunan tidak dapat menyelesaikan masalah pasar (PKL dan kemacetan ), ditengarai setelah direnovasi pasar tidak lebih laku dari sebelumnya dan relokasi sementara pada proses pembangunan menurunkan kinerja usaha pedagang. Sementara dukungan pembangunan dari masyarakat terbilang tinggi.Hal ini karena masyarakat menginginkan pasar yang nyaman, bersih, sehat, tersedia ragam, kuantitas dan kualitas barang, harga yang murah, sarana rekreasi, mendukung kegiatan sosial dan ekonomi penduduk dan alasan lainnya.Dukungan ini menunjukan keberadaan Pasar Banjaran yang lebih baik didambakan masyarakat.Demikian pula dengan pemerintah yang ingin memberikan pelayanan publik yang lebih baik.Sementara itu, apabila pembangunan dilaksanakan maka pilihannya kepada renovasi, dibandingkan relokasi. Untuk lebih jelasnya mengenai antusiasme stakeholders tersebut dapat dilihat pada tael di bawah ini.

\section{Revitalisasi Non Fisik dan Fisik Pasar Banjaran}

Berdasarkan kajian, secara umum stakeholders Pasar Banjaran memilih bentuk renovasi dalam pembangunan ini.Pilihan tersebut berdasarkan pertimbangan kinerja usaha pasar, pilihan relokasi 


\section{Kebijakan: Jurnal Ilmu Administrasi \\ Volume 12, Nomor 1, Januari 2021 \\ E-ISSN: 2656-2820 \\ P-ISSN 1829-5762}

tidak mendapat dukungan signifikan karena relokasi tidak dapat menjamin kinerja pasar paska pembangunan.Pembangunan harus dilakukan secara menyeluruh meliputi seluruh aspek pasar.Pembangunan parsial tidak akan dapat meningkatkan daya saing pasar. Pembangunan terdiri dari 2 jenis, yaitu: pembangunan yang berbentuk non fisik dan fisik. Pembangunan non fisik adalah pembangunan terhadap komponen-komponen non fisik, seperti: pedagang, pengelolaan, peraturan, dll. Sementara pembangunan fisik adalah pembangunan terkait bangunan pasar.

1. Revitalisasi Non Fisik Pasar Banjaran

Ada 2 (dua) komponen yang harus diperhatikan alam pembangunan non fisik Pasar Banjaran. Ke-2 komponen tersebut, yaitu: pembangunan terhadap kinerja pedagang, dan pembangunan terhadap kinerja pengelolaan pasar. Pembangunan ke-2 komponen tersebut harus diiringi dengan penegakan aturan yang konsisten. Tujuan dari pembangunan non fisik tidak lain adalah tercapainya pelayanan yang professional. Tercapainya profesinalisme ini merupakan upaya pasar meningkatkan daya saingnya. Beberapa kondisi pasar yang harus diperhatikan dalam pembangunan adalah:

1) Pedagang Pasar

a. Jumlah pedagang yang semakin meningkat, kecenderungan bertambahnya jumlah pedagang yang ingin berjualan di pasar dari waktu ke waktu mengalami peningkatan. Hal ini berdampak pada kebutuhan tempat yang juga semakin meningkat. Jika tempat tidak tersedia, maka timbul pemaksaan dan mengabaikan tata ruang pasar.

b. Kesadaran terhadap kedisiplinan, kebersihan dan ketertiban, para pedagang perlu memahami tentang perlunya kedisiplinan, kebersihan dan ketertiban. Kondisi ini perlu disiasati dengan melakukan proses edukasi atau pelatihan secara berkala terhadap pada pedagang.

c. Pemahaman terhadap perilaku konsumen, selera konsumen selalu berubah-ubah, tetapi para produsen dan pedagang tidak bisa mengikutinya karena terbatasnya pengetahuan dan informasi. Mereka pada umumnya berkembang secara alamiah tanpa ada persiapan untuk memasuki era persaingan.

2) Pengelolaan dan Manjemen Pasar

a. Visi dan Misi. Pihak pengelola pasar perlu malakukan revitalisasi terhadap visi dan misi pasar. Revitalisasi ini diperlukan agar arah dan bentuk pasar tradisional yang akan dikembangkan ke depan menjadi jelas.

b. Tugas Pokok Pengelola Pasar.Tugas pokok pengelola pasar adalah melakukan pembinaan terhadap pedagang, menciptakan kondisi pasar yang kondusif dan layak untuk berusaha serta mengupayakan kelancaran distribusi barang sehingga tercipta kestabilan harga barang, terutama kebutuhan pokok masyarakat. Untuk itu pengelola pasar harus dapat menangani manajemen pasar tersebut dengan baik, disamping menunaikan tugas dalam peningkatan Pendapatan Asli Daerah (PAD).

c. Standard Operation Procedure (SOP) yang tidak jelas. Ciri manajemen yang baik adalah apabila setiap fungsi/jabatan di dalam struktur organisasi memiliki tugas dan tanggung jawab yang jelas, kinerjanya dapat diukur yang tertuang di dalam SOP. Saat ini, implementasi SOP pasar tradisional masih perlu ditingkatkan.

d. Manajemen keuangan. Untuk kredibilitas maka pengelolaan keuangan pasar harus akuntabel dan transparan.

e. Perhatian terhadap pemeliharaan sarana fisik. Umur ekonomis bangunan pasar dapat menjadi pendek, apabila tidak dilakukan pemeliharaan yang tepat dan berkala. Di beberapa pasar tradisional, ditemukan bahwa pemeliharaan dilakukan setiap 5 tahun dan umumnya dilakukan atas inisiatif para pedagang sendiri tetapi dengan cara tambal sulam. Kondisi ini menyebabkan pasar tradisional semakin menjadi tidak indah, bersih dan nyaman. Dampaknya, sarana pasar yang seharusnya diperuntukkan untuk bisa bertahan lebih dari 25 
tahun menjadi tidak terwujud. Dengan mudah, pasar yang baru dibangun, kembali menjadi kumuh dalam waktu singkat.

f. Permasalahan Pedagang Kaki Lima (PKL). Pedagang kaki lima memerlukan tempat untuk menjajakan dagangannya. Mereka selalu mencari tempat yang ramai dikunjungi pembeli. Sayangnya, belum ada solusi yang memadai untuk mereka. Cenderung dibiarkan saja, sehingga mereka menempati pinggiran jalan untuk menjual. Akibatnya, terjadi kemacetan lalu lintas angkutan barang dan mengganggu kenyamanan pembeli. Konsep pasar yang dibangun harus mengakomodasi tempat penjualan sektor informal yang layak dan sesuai dengan yang mereka inginkan (tidak harus di pinggir jalan).

g. Premanisme. Salah satu ciri pasar tradisional saat ini adalah banyaknya praktek premanisme yang sangat mengganggu kelancaran dan efisiensi transaksi antara pembeli dan penjual. Mereka terkadang bertindak sebagai perantara yang sebenarnya tidak diperlukan karena hanya melakukan pemaksaan dan percaloan. Selain itu, mereka juga adalah pelaku kriminal yang melakukan praktek perjudian dan pemerasan. Secara langsung, yang menjadi korban adalah para pedagang, tetapi secara tidak langsung pihak konsumen juga menjadi korban karena harus membeli barang dengan harga yang lebih tinggi.

h. Tidak ada pengawasan terhadap barang yang dijual dan standardisasi ukuran dan timbangan. Karena sifatnya terbuka, maka sangat sulit dilakukan pengawasan terhadap barang yang dijual di pasar tradisional. Begitu pula dengan standardisasi ukuran dan timbangan barang yang seringkali tidak dilakukan dengan benar oleh pedagang. Pengelola pasar belum melakukan koordinasi dengan pihak yang berkompeten untuk melaksanakan pengawasan secara rutin demi melindungi kepentingan konsumen.

i. Masalah fasilitas umum. Kelemahan mendasar lainnya dari pasar tradisional adalah kurang tersedianya fasilitas umum yang memadai. Tempat parkir yang sempit, toilet yang kotor dan kadang tidak berfungsi dengan baik, tempat pembuangan sampah sementara yang menggunung dan menimbulkan bau menyengat, koridor atau lorong yang sempit adalah merupakan pemandangan umum yang diketemukan di hampir semua pasar tradisional di Indonesia.

j. Penataan los/kios/lapak yang tidak beraturan .Kesemrawutan pasar tradisional juga disebabkan oleh karena tidak adanya kemampuan dan ketegasan oleh manajemen pasar dalam mengatur kios dan lapak secara baik dan rapi. Pengelola harus dapat bersikap dan bertindak tegas dalam menertibkan serta mengenakan sanksi terhadap para pelanggar yang menggunakan ruangan yang bukan peruntukannya.

\section{Pengembangan/Pemberdayaan Pedagang}

Pengembangan/memberdayakan pedagang pasar maka perlu dilakukan upaya-upaya yang terarah, konsisten dan berkesinambungan.Keterarahan dan konsistensi pengembangan/pemberdayaan pedagang diperlukan agar tingkat efektifitas program tinggi. Berkesinambungan diperlukan agar pengembangan/pemberdayaan pedagang dapat dilaksanakan secara menyeluruh dari waktu ke waktu dan dari generasi ke generasi. Beberapa aspek yang harus dikembangkan dalam pembangunan pedaganga pasar, diantaranya adalah:

\section{a) Pembinaan Disiplin Pedagang}

Dibuat aturan main yang jelas dan disosialisasikan kepada para pedagang. Pengelola pasar harus membuat peraturan yang jelas dan kemudian dilakukan sosialisasi dan proses edukasi kepada para pedagang secara rutin dan menyeluruh sehingga semua penghuni pasar mengetahui isi dan maksudnya. Jika ada yang tidak disetujui oleh penghuni pasar maka harus dilakukan pertemuan khusus untuk melakukan perubahan sehingga bisa diterima dengan baik. Jika sudah 
diterima, selanjutnya diminta komitmen dari penghuni pasar untuk menaatinya. Agar bisa selalu diingat oleh para penghuni pasar, maka naskah peraturan dibuat menjadi semenarik mungkin dan ditempel di berbagai tempat di lokasi pasar.

b) Penegakan aturan dan pengenaan sanksi yang tegas pada setiap pelanggaran. Pengelola pasar harus bisa bertindak tegas untuk mengenakan sanksi bagi setiap yang melakukan pelanggaran. Jangan bertindak diskriminatif dan harus konsisten menjalankan peraturan. Pasar akan terjaga ketertibannya apabila pelaku-pelaku di dalamnya menaati peraturan dengan baik dan konsekuen.

c) Ciptakan pola pengamanan bersama. Petugas sekuriti terbatas jumlahnya, karena itu harus dibantu oleh semua penghuni pasar agar tercipta suatu pola pengamanan bersama. Setiap pedagang atau penghuni harus memiliki tanggung jawab tertentu terhadap keamanan pasar.

3. Edukasi Untuk Menciptakan Pasar Yang Bersih, Indah dan Higienis

Edukasi perlu dilakukan terus menerus terhadap para pedagang penghuni pasar.Hal ini dilakukan agar para penghuni bisa menyadari perlunya memelihara dan membuat pasar menjadi indah, nyaman, bersih dan sehat baik untuk penghuni maupun untuk pengunjung atau pembeli.Mereka harus selalu disadarkan bahwa persaingan semakin ketat sehingga diperlukan berbagai upaya untuk menarik para pembeli untuk berbelanja di lokasinya. Dalam kaitan ini, diperlukan upaya-upaya agar para pedagang penghuni pasar senantiasa:

4. Pemahaman Terhadap Perilaku konsumen

Pola perilaku konsumen dewasa ini telah mengalami perubahan.Mereka tidak saja menginginkan kualitas dan harga produk yang bagus, tetapi juga kualitas tempat (pasar) yang memadai dan layak sesuai dengan tingkat pendapatannya. Secara umum, tempat yang nyaman, aman dan memadai akan menjadi pilihan utama bagi kebanyakan pembeli. Kondisi ini harus bisa menjadi perhatian serius dari para pedagang di pasar tradisional.Walaupun tradisional tetapi tetap memiliki daya tarik untuk dikunjungi oleh para calon pembeli. Pedagang harus mengetahui bahwa persaingan tidak hanya terbatas pada kualitas dan harga produk, tetapi juga sudah pada tataran lain yaitu bagaimana memuaskan pelanggan dari faktor yang lainnya, seperti adanya kenyamanan berbelanja dan adanya nuansa khusus menarik lainya yang tidak dimiliki oleh pasar modern.

5. Standart Operation Procedure (SOP) Manajemen Pasar

Agar semua tugas bisa dilaksanakan secara tertib dan menghindari terjadinya penyimpangan yang tidak diinginkan, maka diperlukan adanya SOP yang bisa diuraikan sebagai berikut:

Tabel 5. Standart Operation Procedure (SOP) Manajemen Pasar

\begin{tabular}{|l|l|}
\hline \multicolumn{1}{|c|}{$\begin{array}{c}\text { Standart } \\
\text { Operation } \\
\text { Procedure } \\
\text { (SOP) }\end{array}$} & \multicolumn{1}{|c|}{$\begin{array}{l}\text { KegiatanStandart Operation Procedure (SOP) } \\
\text { Manajemen Pasar }\end{array}$} \\
\hline $\begin{array}{l}\text { Manajemen } \\
\text { keuangan yang } \\
\text { terpusat }\end{array}$ & $\begin{array}{l}\text { Manajemen keuangan yang terpusat, khususnya dalam hal Collecting fee dari } \\
\text { pedagang / penyewa } \\
\text { a. Pedagang membayar kewajiban secara langsung kepada petugas yang } \\
\text { ditunjuk, tidak ada petugas lain dilapangan yang boleh menerima uang dari } \\
\text { penyewa. } \\
\text { b. Hanya terdapat 1 (satu) jenis fee yang dibebankan kepada penyewa, di } \\
\text { dalamnya sudah meliputi biaya sewa, kebersihan, keamanan dan pemeliharaan. } \\
\text { Besarnya fee telah disetujui bersama antara manajemen dan penyewa. }\end{array}$ \\
\hline Hak Pakai & \begin{tabular}{l} 
a. Untuk tempat usaha dalam bentuk kios, Hak Pakai idealnya tidak lebih dari \\
\hline
\end{tabular} \\
\hline
\end{tabular}




\begin{tabular}{|c|c|}
\hline & $\begin{array}{l}5 \text { (lima) tahun. Hal ini untuk mempermudah melakukan upaya-upaya dalam } \\
\text { hal apabila pemegang hak tidak membuka kiosnya. } \\
\text { b. Untuk tempat usaha dalam bentuk los, hak pakai idealnya tidak lebih dari } 3 \\
\text { (tiga) bulan, dikarenakan biasanya pedagang los sifatnya musiman. }\end{array}$ \\
\hline $\begin{array}{l}\text { Keamanan \& } \\
\text { Ketertiban }\end{array}$ & $\begin{array}{l}\text { a. Agar lebih terjamin, pemeliharaan dan peningkatan ketertiban di lingkungan } \\
\text { pedagang harus melibatkan semua penyewa untuk meringankan tugas para } \\
\text { petugas keamanan. } \\
\text { b. Tugas keamanan dan ketertiban secara umum dilakukan oleh Security. } \\
\text { c. Setiap blok kios terdapat petugas keamanan yang bertanggung-jawab } \\
\text { melakukan pengawasan secara reguler. } \\
\text { d. SDM bidang keamanan adalah orang terlatih yang direkrut dari lingkungan } \\
\text { sekitar maupun eks-preman yang terikat kontrak. }\end{array}$ \\
\hline $\begin{array}{l}\text { Kebersih } \\
\text { Sampah }\end{array}$ & $\begin{array}{l}\text { a. Pembersihan tempat dilakukan secara terus-menerus, tidak berdasarkan } \\
\text { jadwal, tetapi situasional berdasar keadaan di tempat. } \\
\text { b. Setiap kelompok kios terdapat tempat penampungan sampah sementara, } \\
\text { kemudian secara berkala dipindahkan ke tempat penampungan akhir oleh } \\
\text { petugas yang disewa oleh manajemen pasar. } \\
\text { c. Sampah akhir yang terkumpul pada tempat penampungan akhir di angkut ke } \\
\text { luar pasar } 2 \text { (dua) kali sehari. }\end{array}$ \\
\hline & $\begin{array}{l}\text { Tidak ada tempat parkir yang diblok/direserved untuk pelanggan sehingga } \\
\text { semua memiliki hak yang sama atas tempat parkir.1Tempat parkir harus } \\
\text { tersedia cukup luas untuk menampung kendaraan para pengunjung. }\end{array}$ \\
\hline $\begin{array}{l}\text { Pemeliharaan } \\
\text { Sarana Pasar }\end{array}$ & $\begin{array}{l}\text { Secara rutin, manajemen pasar harus melakukan pengecekan terhadap kondisi } \\
\text { fisik bangunan dan sarana fisik lainnya. Pada saat melakukan pengecekan, } \\
\text { petugas harus mengisi check-list yang dibawanya dan langsung melakukan } \\
\text { pelaporan begitu pengecekan selesai dilakukan. Setelah menerima laporan, } \\
\text { Bagian Pemeliharaan harus segera melakukan tindakan jika harus dilakukan } \\
\text { pemeliharaan atau perbaikan. Jangan menunggu hingga kondisi kerusakan } \\
\text { menjadi lebih parah sehingga mengganggu aktivitas pasar. }\end{array}$ \\
\hline Penteraan & $\begin{array}{l}\text { Secara berkala, dilakukan penteraan terhadap alat ukur di pasar khususnya } \\
\text { timbangan. Tujuannya disamping menjamin kepastian ukuran di pasar juga } \\
\text { untuk membangun kepercayaan konsumen. Ini dilakukan melalui koordinasi } \\
\text { dan kerjasama dengan dengan Dinas Metrologi setempat. }\end{array}$ \\
\hline $\begin{array}{l}\text { Penanganan } \\
\text { Distribusi Barang }\end{array}$ & $\begin{array}{l}\text { Manajemen pasar harus menyiapan lokasi khusus untuk penanganan distribusi } \\
\text { dan delivery barang masuk ke pasar. Ini juga akan memudahkan dilakukannya } \\
\text { pengawasan terhadap barang yang masuk ke pasar. Untuk barang yang masuk, } \\
\text { terlebih dahulu harus dilakukan penyortiran atau pengolahan awal sebelum } \\
\text { dijajakan di tempat penjualan: } \\
\text { a. Untuk komoditi pertanian diakukan penyortiran terhadap barang yang sudah } \\
\text { busuk. } \\
\text { b. Untuk ayam potong disediakan tempat pengolahan/pemotongan dan } \\
\text { pembersihan di luar area dagangan. } \\
\text { c. Untuk bahan makanan (bakso, mie basah, dll) dilakukan pengetesan (kertas } \\
\text { lakmus) untuk mengetahui kandungan bahan aditif. }\end{array}$ \\
\hline
\end{tabular}




\begin{tabular}{|l|l|}
\hline d. Untuk makanan kemasan dilakukan pengawasan terhadap masa \\
kadaluwarsanya (expired date) \\
Selain itu, harus tersedia tempat penyimpanan atau gudang yang aman dan bisa \\
membuat barang dagangan tahan lama atau tidak cepat rusak: \\
a. Harus ada gudang dengan suhu normal dan tidak ada tikus atau binatang \\
perusak lainnya \\
b. Harus ada cold storage untuk bahan yang tidak tahan lama. \\
$\begin{array}{l}\text { Dengan demikian, kios di dalam pasar bisa secara optimal hanya berfungsi } \\
\text { sebagai tempat menjajakan dagangan, bukan tempat penumpukan barang. }\end{array}$
\end{tabular}

Sumber: Analisis Sosial EkonomiPembangunan Pasar Banjaran 2013.

6. Jenis dan Luas, Prioritas Kepemilikan Berdasarkan Perda No.20/2009 Kabupaten Bandung

Jenis dan Luas Kios/Los dan Sarana Prasarana, berdasarkan Perda No.20/2009, ukuran ruang usaha toko paling sedikit seluas $3 \times 3 \mathrm{~m} 2$, ukuran kios paling sedikit seluas $2 \times 3 \mathrm{~m} 2$ dan ukuran los/lapangan paling sedikit $1 \times 1,5 \mathrm{~m} 2$. Sementara prioritas kepemilikan utama toko, kios, dan los/lapangan adalah pedagang lama. Penyesuain ukuran dapat dilakukan namun harus melalui kajiandari tim teknis yang dibentuk.

7. Prioritas Penempatan/Kepemilikan Kios/Los

Berdasarkan Perda No.20/2009 setiap pelaksanaan pembangunan rasar baik renovasi maupun relokasi peruntukkannya diprioritaskan bagi pedagang lama yang memiliki legalitas dan selebihnya untuk konsumen/pedagang lainnya. Oleh karenanya pedagang lama dan PKL harus mendapatkan prioritas utama untuk menempati Pasar Banjaran.

8. Survey Harga Kios /Los dan Pendapat Pedagang

Harga/Sewa kios/Los di pasar lain berlantai 1 (satu) yang sudah ditingkatkan kualitas fisiknya berada pada kisaran paling sedikit Rp.4.000.000,-/m2 untuk los dan Rp. 5.000.000,-/m2 untuk kios. Harga tersebut berlaku bagi pedagang lama. Sementara bagi pedagang baru berada kisaran paling sedikit Rp. 9.000.000,- Sementara harga sewa kios/los berada pada kisaran paling sedikit Rp. 5.000,per hari. Sementara biaya swadaya pembanguna Pasar Banjaran berada pada kisaran Rp. 1.750.000,/m2.Berdasarkan Perda No.20/2009 penentuan harga jual kios dan sewa los harus melibatkan pedagang.Karena pedagang memiliki historis dan konstribusi tidak sedikit terhadap keberadaan Pasar Banjaran.Untuk lebih jelasnya mengenai kisaran harga kios/los dapat melihat pada table dibawah ini.

Tabel 6. Kisaran Tarif Harga/Sewa Kios dan Los di Kabupaten Bandung dan Sekitarnya

\begin{tabular}{|c|c|c|c|}
\hline Lokasi Kios/Los & $\begin{array}{c}\text { Jenis Ruang } \\
\text { Usaha }\end{array}$ & $\begin{array}{c}\text { Sistem } \\
\text { Pembayaran }\end{array}$ & Kisaran Harga \\
\hline \multirow{2}{*}{$\begin{array}{lr}\text { Pasar } & \text { Tradisional } \\
\text { Modern } & \text { Milik } \\
\text { Swasta } & \end{array}$} & Los & Sewa & $\begin{array}{l}\text { Kisaran Rp. } 5.000 \mathrm{~s} / \mathrm{d} \\
25.000,- \text { per hari (lantai } 1 \text { dan } 2)\end{array}$ \\
\hline & Kios & $\begin{array}{l}\text { Jual (Hak } \\
\text { Guna } \\
\text { Pakai/hak } \\
\text { Milik) }\end{array}$ & $\begin{array}{l}\text { - } 1 \text { (satu) LantaiRp. } 4.000 .0000,-\mathrm{s} / \mathrm{d} \\
\text { Rp. 5.000.000,- bagiPedagang Lama dan } \\
>\text { Rp. } 9.000 .000,- \text { per } \mathrm{m} 2 \text { bagi pedagang } \\
\text { baru. } \\
\text { - Lebih dari } 1 \text { (satu) } \\
\text { Lantai: paling sedikit } \\
\text { Rp. } 10.000 .0000,-\end{array}$ \\
\hline $\begin{array}{l}\text { Pembangunan } \\
\text { Swadaya }\end{array}$ & & $\begin{array}{l}\text { Hak Guna } \\
\text { Pakai }\end{array}$ & Berada pada kisaran Rp. $1.750 .000,-/ \mathrm{m} 2$ \\
\hline
\end{tabular}


Pendapat Pedagang: Harga kios/los bagi pedagang baru berbeda dengan pedagang lama, harga pembangunan swadaya hendaknya dijadikan acuan dan disertakan dalam penentuan harga.

Sumber: Analisis Sosial Ekonomi Pembangunan Pasar Banjaran 2013.

\section{Analisis Keuangan dan Investasi}

1. Perhitungan Biaya Pembangunan Pasar dan Terminal Terpadu

Besarnya biaya yang diperlukan dalam pembangunan ini sebesar Rp. 56.750.364.740,-. Angka tersebut didapat dari penjumlahan biaya kegiatan/komponen pembangunan yang meliputi biaya pembangunan pasar, terminal, jalan, area parkir, landskaping, urugan, pembebasan lahan, administrasi, operasinal dan perijinan ditambah pembayaran bunga kredit pembiayaan konstruksi sebesar $12 \%$ flat. Untuk lebih jelasnya dapat dilihat pada tabel di bawah ini.

Tabel 7. Perhitungan Biaya Pembangunan Pasar dan Terminal Banjaran Terpadu

\begin{tabular}{|c|c|c|c|}
\hline Kegiatan & \multicolumn{2}{|c|}{ Perhitungan Biaya } & \multirow[t]{2}{*}{ Jumlah (Rp) } \\
\hline & Satuan $(\mathrm{m} 2)$ & Harga (Rp) & \\
\hline Pembangunan Fisik & 16.800 & $2.500 .000,-$ & 42.000.000.000,-- \\
\hline Pembangunan Terminal & $5.679,15$ & $3.000 .000 \times 0,3(\mathrm{kf})$ & $5.111 .235 .000,-$ \\
\hline Area Parkir & 500 & $3.000 .000 \times 0,3(\mathrm{kf})$ & $450.000 .000,-$ \\
\hline Pembangunan Jalan & 1.200 & $3.000 .000 \times 0,3(\mathrm{kf})$ & $1.080 .000 .000,-$ \\
\hline Landscaping & 1.200 & $250.000,-$ & $300.000 .000,-$ \\
\hline Urugan $E R S$ & 16.800 & $50.000 \times 0,5(\mathrm{kf})$ & $275.000 .000,-$ \\
\hline Pembebasan Lahan & 900,25 & IIIU 2.000.000,- & $1.886 .500 .000,-$ \\
\hline Operasional (overhead) & Lsm & Lsm & $750,000,000,-$ \\
\hline Perijinan & & & $500.000 .000,-$ \\
\hline $\mathrm{N}_{4 \mathrm{~S}}$ & 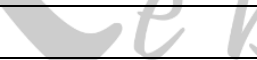 & Jumlah & $52.352 .735 .000,-$ \\
\hline \multicolumn{3}{|c|}{ BungaBank 70\% x Dana Pinjam Bank x $12 \%$ Flat } & 4.397.629.740,- \\
\hline \multicolumn{3}{|c|}{ Jumlah Keselutuhan Biaya Pembangunan } & $56.750 .364 .740,-$ \\
\hline
\end{tabular}

Sumber: Analisis Sosial Ekonomi tahun 2013.

\section{Analisis Keuangan}

Perhitungan harga jual terkait erat dengan biaya investasi.Perhitungan biaya investasi didasari oleh hasil survey mengenai harga kios/los yang telah dilakukan.Untuk lebih jelasnya mengenai analisis keuangan dan investasi pembangunan pasar dan terminal terpadu dapat dilihat pada table dibawah ini.

Tabel 8. Analsis Keuangan Pembangunan Pasar dan Terminal Banjaran Terpadu

\begin{tabular}{|l|l|r|r|r|}
\hline \multicolumn{1}{|c|}{$\begin{array}{c}\text { Jenis } \\
\text { Ruang } \\
\text { Usaha }\end{array}$} & $\begin{array}{l}\text { Jumlah Ruang } \\
\text { Usaha (unit) }\end{array}$ & $\begin{array}{c}\text { Luas Ruang } \\
\text { Usaha (m2) }\end{array}$ & $\begin{array}{c}\text { Harga Per } \\
\text { Meter } \\
(\mathbf{R p} / \mathbf{m} 2)\end{array}$ & \multicolumn{1}{|c|}{ Jumlah (Rp) } \\
\hline $\begin{array}{l}\text { Kios Pasar } \\
1,2 \text { dan 3 }\end{array}$ & $\begin{array}{l}549 \text { unit } \\
(2,5 \times 3 \mathrm{~m} 2)\end{array}$ & 4117,50 & $2.625 .000,-$ & $10.808 .437 .500,-$ \\
\hline $\begin{array}{l}\text { Los Pasar } \\
1\end{array}$ & $\begin{array}{l}132 \text { unit } \\
(1 \text { x 1,5 m2) }\end{array}$ & 198,00 & $2.187 .500,-$ & $4.331 .250 .000,-$ \\
\hline Los Pasar & 130 unit & 650,00 & $2.187 .500,-$ & $1.421 .550 .000,-$ \\
\hline
\end{tabular}


Kebijakan: Jurnal Ilmu Administrasi

Volume 12, Nomor 1, Januari 2021

E-ISSN: 2656-2820

P-ISSN 1829-5762

\begin{tabular}{|c|c|c|c|c|}
\hline 2 & $(2 \times 2,5 \mathrm{~m} 2)$ & & & \\
\hline $\begin{array}{ll}\text { Los } & \text { Pasar } \\
3 & \end{array}$ & $\begin{array}{l}111 \text { unit } \\
(1 \times 1,5 \mathrm{~m} 2)\end{array}$ & 277,50 & $2.187 .500,-$ & $607.031 .250,-$ \\
\hline Los PKL & $\begin{array}{l}886 \text { unit } \\
(1 \times 1,5)\end{array}$ & $1.329,00$ & $2.187 .500,-$ & 2.907.187.000,- \\
\hline \multicolumn{4}{|l|}{ Jumlah } & 20.007.545.500,- \\
\hline \multicolumn{4}{|c|}{ Keseluruhan Biaya Pembangunan } & $56.750 .364 .740,-$ \\
\hline \multicolumn{4}{|c|}{ Defisit Anggaran } & $(36.742 .819 .240,-)$ \\
\hline \multicolumn{4}{|c|}{$\begin{array}{l}\text { Penjualan Kelebihan Ruang Usaha 5.044,25 m2 x Rp. } \\
9.000 .000,-\end{array}$} & 45.398.250.000,- \\
\hline \multicolumn{4}{|c|}{ Laba Usaha } & 8.647.885.260,- \\
\hline
\end{tabular}

Sumber: Analisis Sosial Ekonomi Pembangunan Pasar Banjaran 2013.

Perhitungan keuangan pembangunan pasar dan terminal terpadu Pasar diatas dapat dilihat dari analisis keuangan sebagai berikut:

a) Nett Profit Margin = Laba Bersih/Penjualan

$=$ Rp. 8.647.885.260,- /Rp. 56.750.364.740,-

$=15,23 \%$

b) $\quad$ ROI $=$ Laba Bersih/Modal

$=$ Rp.8.647.885.260,- $/ \mathrm{Rp} \cdot 15.705 .820 .500,-$

$=55,10 \%$

c) Break Even Point $(\mathrm{BEP})=$ Defisit Anggaran/Luas Ruang Usaha

$=$ Rp. $36.742 .819 .240,-/ 5044,25 \mathrm{~m} 2$

$=$ Rp. 7.284.099,- $/ \mathrm{m} 2$

3. Kebijakan Investasi

a) Strategi Penentuan Harga : Penentuan harga dilakukan dengan pertimbangan harga kios/los dipasar lain (walaupun keadaan pasar berbeda), luasan ruang usaha, subsidi terhadap pedagang lama dari pedagang baru, dan pembiayaan pembangunan. Penetapan harga dilakukan dengan pendeketan optimum terhadap faktor-faktor tersebut.

b) Subsidi dan Tingkat Profitabilitas :Harga kios dan los ditentukan dengan menggunakan pendekatan minimal dengan mempertimbangkan daya beli padagang lama dan baru.Pengurangan subsidi dan peningkatan keuntungan dapat ditingkatkan dengan penambahan harga, menambah ruang usaha dengan bangunan pasar menjadi 3 lantai, dan kreatifitas kegiatan, dan upaya-upaya lainnya.Melalui peningkatan pendapatan ini maka subsidi berkurang bahkan hilang dan indikator investasi semakin baik.

c) Developer Pembangunan Pasar Banjaran: Besarnya biaya yang diperlukan menjadi pertimbangan dalam pembangunan/revitalisasPasar Banjaran. Apabila kemampuan dana pemerintah, baik APBD/APBN terbatas maka pembangunan Pasar Banjaran memerlukan keterlibatan pihak ke tiga (investor). Keterlibatan pihak ke tiga sangat penting, namun sebagai investor maka prinsip mendapatkan keuntungan sebanyak-banyak harus menjadi catatan. Harga kios/los bagi pedagang lama harus sesuai dengan kemampuan pedagang dan pedagang harus disertakan keterlibantaanya dalam perencanaan. Kemudian Pemerintah Kabupaten melalui Kementerian Perdagangan dapat mengakses dana internasional terutama dana murah atau hibah melalui kerjasama $\mathrm{G}$ to $\mathrm{G}$. 
d) Kerjasama Developer Dengan Pemerintah Kabupaten :Pembangunan pasar membutuhkan dana yang besar. Paling ideal pembangunan pasar dilakukan oleh Pemerintah Kabupaten melalui APBD dan APBN.Namun pembangunan juga dapat dilakukan oleh developer (swasta). Karena lahan pasar milik Pemerintah Kabupaten dan dana berasal dari developer maka ke dua belah pihak harus bekerjasama.

e) Benifit Pembangunan Pasar: Bagi pemerintah pembangunan pasar merupakan upaya untuk penyediaan sarana prasarana public, khususnya dalam bidang perdagangan.Pembangunan diharapkan dapat meningkatkan daya saing pasar. Peningkatan daya saing ini dapat meningkatkan pendapatan pedagang (pasar dan bukan pedagang pasar), masyarakat, distributor dan produsen. Lebih dari itu keberadaan pasar dapat meningkatkan lapangan kerja dan kegiatan-kegiatan di sektr riil.Peningkatan ini juga berdampak terhadap Pendapatan Asli Daerah (PAD).

f) Permasalahan Pembebasan Lahan Pribadi : Permasalahan pembebasan lahan merupakan bagian yang harus dapat diselesaikan dalam pembangunan ini.Permasalahan ketidakcocokan harga harus dapat diselesaikan.Penyelesain tersebut dapat dilakukan dengan kompromi harga atau kerjasama pengelolaan.Kompromi harga merupakan jalan terbaik dalam penyelesain permasalahan ini.Namun apabila masih belum ada titik temu maka kerjasama pengelolaan dapat dilakukan antara UPTD Pasar Banjaran dengan pemilik.Alternative kerjasama, yaitu, pihak UPTD melalui pembangunan membangun lahan tersebut sesuai rancangan kegiatan pasar. Kemudian dilakukan kerjasama pengelolaan yang meliputi: pemeliharaan dan pengelolaan, system penarikan retribusi, dan bagi hasil retribusi. Dalam kerjasama ini status kepemilikan masih tetap pemilik lama.

\section{Usulan Penanganan Masalah}

Tabel 9. Aspek Revitalisasi: Pra Kondisi Dalam Pembangunan Pasardan Terminal Banjaran Terpadu

\begin{tabular}{|c|c|c|c|}
\hline $\begin{array}{c}\text { Aspek } \\
\text { Pembangunan: } \\
\text { Pra Kondisi }\end{array}$ & Permasalahan & $\begin{array}{l}\text { Jalan Keluar } \\
\text { (Way Out) }\end{array}$ & $\begin{array}{c}\text { Pelaksana } \\
\text { (Penanggungjaw } \\
\text { ab) }\end{array}$ \\
\hline $\begin{array}{l}\text { Kondisi } \\
\text { geografis, } \\
\text { demografi dan } \\
\text { sarana prasarana } \\
\text { wilayah }\end{array}$ & $\begin{array}{l}\text { Kondisi geografis dan sarana } \\
\text { prasarana wilayah dapat } \\
\text { menyebabkan distribusi } \\
\text { produk pasar kepada } \\
\text { masyarakat menjadi } \\
\text { terhambat. Sementara aspek } \\
\text { demografi menyebabkan pasar } \\
\text { harus memberikan layanan } \\
\text { beragam berdasarkan tingkatan } \\
\text { usia penduduk }\end{array}$ & $\begin{array}{l}\text { Memperbaiki sarana } \\
\text { prasarana transportasi } \\
\text { dan memberi layanan } \\
\text { berdasarkan segmentasi } \\
\text { penduduk. }\end{array}$ & $\begin{array}{l}\text { UPTD Pasar, } \\
\text { pedagang dan } \\
\text { dinas/instansi } \\
\text { terkait. }\end{array}$ \\
\hline $\begin{array}{l}\text { Kelayakan } \\
\text { pembangunan } \\
\text { pasar }\end{array}$ & $\begin{array}{l}\text { Studi kelayakan pasar harus } \\
\text { dilakukan secara menyeluruh } \\
\text { menyangkut pasar dan } \\
\text { kawasan sekitarnya, } \\
\text { melibatkan seluruh } \\
\text { stakeholders, meliputi } \\
\text { berbagai aspek dan berbagai } \\
\text { keahlian, biaya yang besar dan }\end{array}$ & $\begin{array}{l}\text { Penyusunan studi } \\
\text { kelayakan yang } \\
\text { melibatkan seluruh } \\
\text { stakeholders dan } \\
\text { meliputi berbagai aspek. }\end{array}$ & $\begin{array}{l}\text { Dinas Koperasi } \\
\text { UKM, } \\
\text { Perindustrian dan } \\
\text { Perdagangan } \\
\text { Kabupaten } \\
\text { Bandung }\end{array}$ \\
\hline
\end{tabular}


Kebijakan: Jurnal Ilmu Administrasi

Volume 12, Nomor 1, Januari 2021

E-ISSN: 2656-2820

P-ISSN 1829-5762

\begin{tabular}{|c|c|c|c|}
\hline & cukup waktu, dll. & & \\
\hline $\begin{array}{l}\text { Sosialisasi dan } \\
\text { persepsi } \\
\text { padagang } \\
\text { terhadap } \\
\text { revitaisasi }\end{array}$ & $\begin{array}{l}\text { Kegagalan pembangunan pada } \\
\text { pasar tradisional menyebabkan } \\
\text { antusiasme pedagang menjadi } \\
\text { kurang. Hal ini disebabkan } \\
\text { karena pembangunan akan } \\
\text { menjadi beban dan tidak dapat } \\
\text { merubah apa pun. }\end{array}$ & $\begin{array}{l}\text { Melakukan pendekatan } \\
\text { kepada pedagang, bahwa } \\
\text { pembangunan dilakukan } \\
\text { untuk kepentingan dan } \\
\text { kemajuan usaha mereka. }\end{array}$ & $\begin{array}{l}\text { Dinas Koperasi } \\
\text { UKM, } \\
\text { Perindustrian dan } \\
\text { Perdagangan } \\
\text { Kabupaten } \\
\text { Bandung dan } \\
\text { UPTD Pasar }\end{array}$ \\
\hline $\begin{array}{l}\text { Komitmen } \\
\text { Pemerintah }\end{array}$ & $\begin{array}{l}\text { Sebagai pihak yang } \\
\text { bertanggung jawab terhadap } \\
\text { pelayanan public komitmen } \\
\text { pemerintah terhadap } \\
\text { pembangunan cukup tinggi. } \\
\text { Namun terkendala karena } \\
\text { keterbatasan anggaran. }\end{array}$ & $\begin{array}{l}\text { Bermitra dengan } \\
\text { investor yang } \\
\text { mempunyai komitmen } \\
\text { untuk mengembangkan } \\
\text { usaha kecil dan mikro. }\end{array}$ & $\begin{array}{l}\text { Dinas Koperasi } \\
\text { UKM, } \\
\text { Perindustrian dan } \\
\text { Perdagangan } \\
\text { Kabupaten } \\
\text { Bandung }\end{array}$ \\
\hline $\begin{array}{l}\text { Karakter dan } \\
\text { persepsi investor }\end{array}$ & $\begin{array}{l}\text { Karakteristik investor sebagai } \\
\text { entitas bisnis menyebabkan } \\
\text { pasar menjadi obyek dalam } \\
\text { mencari keuntungan. } \\
\text { Sementara pembangunan pasar } \\
\text { dianggap sarat dengan } \\
\text { permasalahan. }\end{array}$ & $\begin{array}{l}\text { Mengembangkan } \\
\text { kerjasama yang } \\
\text { menyeluruh, mulai dari } \\
\text { tingkat perencanaan, } \\
\text { pembangunan dan paska } \\
\text { pembangunan. }\end{array}$ & $\begin{array}{l}\text { Investor dan } \\
\text { Dinas Koperasi } \\
\text { UKM, } \\
\text { Perindustrian dan } \\
\text { Perdagangan } \\
\text { Kabupaten } \\
\text { Bandung }\end{array}$ \\
\hline $\begin{array}{l}\text { Komitmen } \\
\text { lembaga } \\
\text { keuangan }\end{array}$ & $\begin{array}{l}\text { Keberhasilan pembangunan } \\
\text { pasar menjadi pertimbangan } \\
\text { utama bagi lembaga keuangan. }\end{array}$ & $\begin{array}{l}\text { Proposal kelayakan } 111 \\
\text { pembangunan harus } \\
\text { dapat menjawab } \\
\text { keraguan lembaga } \\
\text { keuangan }\end{array}$ & Investor 1 \\
\hline $\begin{array}{l}\text { Program } \\
\text { pembiayaan } \\
\text { pemerintah bagi } \\
\text { KUKM }\end{array}$ & $\begin{array}{l}\text { Realisasi program pemerintah } \\
\text { dalam pembiayaan usaha kecil } \\
\text { dan mikro perlu upaya yang } \\
\text { lebih. }\end{array}$ & $\begin{array}{l}\text { Proposisi pembangunan } \\
\text { pasar kepada pemerintah } \\
\text { propinsi dan } \\
\text { kementerian yang } \\
\text { membidangi KUKM dan } \\
\text { perdagangan. }\end{array}$ & $\begin{array}{l}\text { Dinas Koperasi } \\
\text { UKM, } \\
\text { Perindustrian dan } \\
\text { Perdagangan } \\
\text { Kabupaten } \\
\text { Bandung }\end{array}$ \\
\hline Perijinan & $\begin{array}{l}\text { Kelengkapan persyaratan } \\
\text { menjadi kendala karena } \\
\text { memerlukan kordinasi dengan } \\
\text { berbagai pihak. }\end{array}$ & $\begin{array}{l}\text { Melengkapi persyaratan } \\
\text { sesuai ketentuan. }\end{array}$ & $\begin{array}{l}\text { Dinas Koperasi } \\
\text { UKM, } \\
\text { Perindustrian dan } \\
\text { Perdagangan } \\
\text { Kabupaten } \\
\text { Bandung }\end{array}$ \\
\hline
\end{tabular}

Sumber: Analisis Sosial EkonomiPembangunan Pasar Banjaran 2013.

\section{SIMPULAN}

Berdasarkan kajian sosial, ekonomi, sarana prasarana dan arsitektural pembangunan kembali Pasar Banjaran perlu dilakukan dengan segera. Hal ini terkait dengan kebutuhan saat ini dan dalam mengahadapi tantangan masa yang akan datang. Pembangunan non fisik, meliputi: peningkatan fungsi, peran dan strategi pengelolaan pasar (master plan revitalisasi fungsi dan strategi pengelolaan pasar), pengembangan SDM, peningkatan profesionalitas, peraturan dan komitmen untuk 


\section{Kebijakan: Jurnal Ilmu Administrasi \\ Volume 12, Nomor 1, Januari 2021 \\ E-ISSN: 2656-2820 \\ P-ISSN 1829-5762}

mentaatinya, prasarana pengelola, reward dan punishment, pembiayaan dan pengembangan pasar (Pasar Wisata/Malam). Sementara pembangunan fisik melalui penyusunan master plan arsitektural, meliputi: perancangan tapak, fasade, penataan ruang, sarana prasarana, konstruksi dan pengembangan pasar lebih lanjut.

Sosialisasi dan keterlibatan pedagang (melalui paguyuban pedagang) perlu dilakukan sejak awal perencanaan pembangunan. Hal ini dilakukan agar kepentingan pedagang terwakili sejak awal pembangunan. Keterlibatan pedagang ini berdasarkan Perda No.20/2009 tentang peran serta pedagang dalam pembangunan sebuah pasar. Kemampuan daya beli pedagang memerlukan konsep subsidi dalam pembelian kios dan los pasar. Subsidi diberikan terutama bagi pedagang lama dan PKL. Kelebihan ruang usaha pasar dapat dijadikan sebagai sumber subsidi terhadap kios/los pedagang lama dan PKL. Pembangunan memerlukan Pasar Sementara. Keberadaan Pasar Sementara menjadi jalan keluar agar kegiatan pasar tidak berhenti pada saat pelaksanaan pembangunan fisik pasar. Kajian analisis sosial ekonomi ini merupakan salah satu bagian untuk menempuh perijinan pembangunan Pasar Banjaran. Terkait dengan kelengkapan perijinan lainnya maka masih diperlukan kajian lain sesuai dengan kententuan yang terdapat dalam Perda No.20/2009.

\section{SARAN}

Adapun saran yang penulis sampaikan yaiitu pembangunan perlu keterlibatan dan kerjasama seluruh stakeholders, stakeholders tersebut diantaranya, adalah: pedagang, konsumen, penduduk, pedagang disekitar pasar, produsen, UPTD, dinas instansi terkait, dll. Keterlibatan dan kerja sama tersebut karena pembangunan Pasar Banjaran mempunyai kompleksitas yang tinggi. Sebagai solusi terhadap permasalahan yang mungkin timbul maka Usulan Penanganan Masalah pada Laporan ini merupakan jalan keluar (way out) terhadap penyelesaian permasalahan Pembangunan Pasar Banjaran dan merupakan bagian tidak terpisahkan dari rekomendasi ini.

Wujud pelengkap kajian analisis sosial ekonomi ini perlu dilakukan kajian lainnya sebagai syarat lengkap perijinan. Perlunya kajian lain karena pembangunan pasar meliputi berbagai aspek, seperti: UPT, lalu lintas, amdal, dan kajian lainnya. Kajian tersebut merupakan tidak terpisahkan dari kelengkapan perijinan pembangunan pasar sesuai dengan Perda No.20/2009 dan Perbup No.29/2010. Pembangunan pasar, termasuk pasar tradisional yang berada di wilayah hukum Kabupaten Bandung harus beracu kepada Perda No.20/2009 dan Perbup No. 29/2010.

\section{DAFTAR PUSTAKA}

Blank, LT. Engineering Economy, Mc Graw Hill. 1989.

Budiardjo, Eko. Tata Ruang Perkotaan. Alumni. Bandung. 1977.

Catanese Aj, Perencanaan Kota. Erlangga. Jakarta. 1992.

Chasanah, Ifah. Keberadaan Pasar Tradisional Wage Wadaslintang Sebagai Pusat Kegiatan

Ekonomi, Sosial dan Budaya Masyarakat Wadaslintang Kabupaten Wonosobo Tahun 19982005. 2007.

Cravons, David W. Pemasaran Strategis. Jilid 1, Edisi Keempat. Erlangga. Jakarta.1996

De Chiara, J. Standar. Perencanaan Tapak. Erlangga. Jakarta. 1992/

Grigg, NS. Infrastucture Engineering and Management. John Wiley \& Sons. 1988

Jhinghan, ML. Ekonomi Pembangunan dan Perencanaan,terjemahan D. Guritno

PT. Raja Gafindo Persada, Jakarta. 1998

Kabupaten Bandung Dalam Angka 2009. BPS Daerah Kabupaten Bandung. 2009

Kotler, Philip. Manajemen Pemasaran. Edisi Milenium Jilid I \& II.Prenhallind.

Jakarta 2002.

Rahardjo Adisasmita, Pembangunan Pedesaan dan Perkotaan. Graha Ilmu.2006 
Siagian, Sondang P. Manajemen Stratejik. Bumi Aksara. Jakarta.2002

Stanton, William J, Y. Lamarto. Prinsip Pemasaran. Erlangga. Jakarta.1993.

Studi Kelayakan Bisnis. Edisi Kedua. PT. Gramedia. Pustaka Utama. Jakarta. 1999.

Umar, Husein. Metodologi Penelitian Aplikasi dalam Pemasaran. PT. Gramedia Pustaka

White, Edward T. Analisis Tapak. Intermata. Jakarta. 1992.

Keppres No.112/2007 Tentang Penataan dan Pembinaan Pasar Tradisional, Pusat

Perbelanjan dan Toko Modern. 2007

Perbup No.29/2010 Petunjuk Pelaksnaan Tentang Pembangunan, Penataan dan Pengendalian

Pasar Kabupaten Bandung. 2009

Perda No. 3 Tahun 2008 Penataan Ruang dan Wilayah Kabupaten Bandung Tahun 2008. 2008

Perda No.20/2009 Tentang Pembangunan, Penataan dan Pengendalian Pasar Kabupaten Bandung. 2009

Permen Permukiman dan Prasarana Wilayah No. 534/KPTS/M/2001. 2001.

Permendag No.53/2008 Pedoman Pelaksanaan Penataan dan Pembinaan Pasar Tradisional, Pusat Perbelanjan dan Toko Modern. 2008

UU No.27 Tahun 2007 Tentang Penataan Ruang.

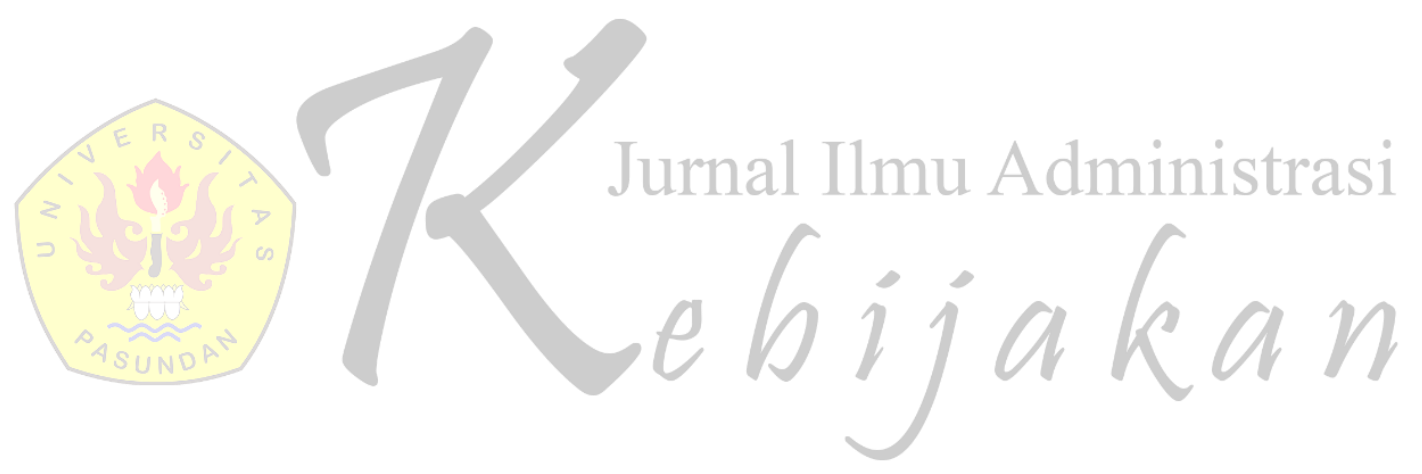

